\title{
Use of perches and seed dispersal by birds in an abandoned pasture in the Porto Ferreira state park, southeastern Brazil
}

\author{
S. Athiê $\hat{e}^{a *}$ and M. M. Dias ${ }^{b}$ \\ aPrograma de Pós-graduação em Ecologia e Recursos Naturais, Universidade Federal de São Carlos - UFSCar, \\ Rodovia Washington Luiz, Km 235, CP 676, CEP 13565-905, São Carlos, SP, Brazil \\ ${ }^{b}$ Departamento de Ecologia e Biologia Evolutiva, Universidade Federal de São Carlos - UFSCar, \\ Rodovia Washington Luiz, Km 235, CP 676, CEP 13565-905, São Carlos, SP, Brazil \\ *e-mail: samira_esalq@yahoo.com.br
}

Received: July 14, 2014 - Accepted: October 17, 2014 - Distributed: February 29, 2016

(With 3 figures)

\begin{abstract}
We investigated the efficiency of different kinds of perches in attracting seed disperser-birds and increasing the seed rain in a degraded area located in the northeast region of São Paulo State. We installed seed traps under natural perches (NPs, living trees); simple artificial perches (SAPs) of $3 \mathrm{~m}$ tall and a crossbar; elaborate artificial perches (EAPs) of $7 \mathrm{~m}$ tall and three crossbars, and in a control area. Results showed the number of bird-dispersed seeds deposited was proportional to the number of structures for perching. The NPs also have provided other resources for birds such as food and shelter. Comparing visitation between artificial perches, there was greater use of EAPs also for having more perching structures and for being taller, providing better airspace visibility for predatory birds and tyrant-flycatchers, important seed dispersers. Thus, natural and artificial perches with similar characteristics to the EAPs are the most recommended as a base or complementary method for the restoration of degraded areas near to propagules source, also contributing to the maintenance of local fauna.
\end{abstract}

Keywords: birds, seed dispersal, frugivory, perches, forest restoration.

\section{Uso de poleiros e dispersão de sementes por aves em um pasto abandonado no Parque Estadual de Porto Ferreira, sudeste do Brasil}

\begin{abstract}
Resumo
Investigamos a eficiência de diferentes modelos de poleiros na atração de aves dispersoras e no incremento da chuva de sementes em uma área degradada localizada na região nordeste do Estado de São Paulo. Instalamos coletores de sementes sob poleiros naturais (PNs, árvores vivas); poleiros artificiais simples (PASs), com 3m de altura e um ponto de pouso; poleiros artificiais elaborados (PAEs), com $7 \mathrm{~m}$ de altura e três pontos de pouso e coletores em área aberta (testemunha). Verificamos que o número de sementes ornitocóricas depositadas nos coletores aumentou proporcionalmente à quantidade de estruturas de pouso dos poleiros. Os PNs também disponibilizaram outros recursos para a avifauna, como alimento e abrigo. Comparando-se a visitação entre os poleiros artificiais, houve maior utilização dos PAEs que, além de apresentarem mais pontos de pouso, são mais altos, fornecendo melhor visibilidade do espaço aéreo para aves predadoras e que apanham insetos em vôo, como os tiranídeos, importantes dispersores de sementes. Neste sentido, poleiros naturais e artificiais com características similares aos PAEs são os mais recomendados como método base ou complementar na restauração de áreas degradadas próximas a fontes de propágulos, contribuindo também para a manutenção da fauna local.
\end{abstract}

Palavras-chave: aves, dispersão de sementes, frugivoria, poleiros, restauração florestal.

\section{Introduction}

In the tropics, 50-90 percent of the trees depend on seed-disperser animals for reproduction (Howe and Smallwood, 1982; Fleming et al., 1987; Holl, 1998; Holl et al., 2000), mainly birds (Carlo and Yang, 2011; Graham and Page, 2012; Cavallero et al., 2013), of which about 20-50 percent of the species consume fruits at least during part of the year, acting as potential seed dispersers (Fleming et al., 1987; Jordano et al., 2006; Jordano, 2014).

Thus, frugivorous birds could be considered as landscape architects because their activity determines in part, vegetation recovery in disturbed habitats (Howe and Miriti, 2004; Cavallero et al., 2013). However, they are 
generally not attracted to visit degraded areas, due to the low availability of fruits, greater exposure to predation and few or no suitable places to stop and rest (Holl, 1998; Graham and Page, 2012).

Knowing the seed dispersal is one of the main forest regeneration barriers (Holl et al., 2000; Shiels and Walker, 2003; Hooper et al., 2005), the use of bird perches has been investigated as a method to increase the seed rain and to accelerate the process of ecological succession in sites to be restored (Guevara and Laborde, 1993; Zanini and Ganade, 2005; Carlo and Yang, 2011).

Studies evaluating the effectiveness of perches in temperate and tropical ecosystems have reported an increase of propagules input in disturbed and degraded areas (Wunderle, 1997; Holl, 1998; Shiels and Walker, 2003; Carlo and Yang, 2011; Cavallero et al., 2013) since they create stopping and resting points for birds to regurgitate and defecate seeds (Jordano et al., 2006; Graham and Page, 2012). These recruitment foci act as centers of seedling establishment, contributing to the dynamics of ecological succession (Cavallero et al., 2013).

Bird perches can be natural, such as remnant trees, live fences and dead trees, or artificial, such as wooden poles and structures made from bamboo (McClanahan and Wolfe, 1993). May also vary in number of landing points, height and distance from the nearest seed source, among others. However, few studies have compared the efficiency of perches with different designs on visitation and seed deposition by birds.

In this sense, the present study aimed to investigate the influence of different kinds of perches on visitation by birds and increasing of the seed rain in an abandoned pasture close to remnants of semideciduous forest and savanna in the northeast region of São Paulo State. We focused in answer the following questions: 1) Do perches improve seed deposition by birds in comparison to the open area? 2) Which bird species use the perches and which plant species are disseminated? 3) Does the architecture of perches interfere in the visitation and seed deposition? 4) Are there qualitative and quantitative changes due to the climatic seasonality?

\section{Material and Methods}

\subsection{Study area}

This study was conducted in the Porto Ferreira State Park (PFSP), a Conservation Unity belonging to São Paulo State Forest Institute. Located in Porto Ferreira city $\left(21^{\circ} 49^{\prime} \mathrm{S}\right.$ and $\left.47^{\circ} 25^{\prime} \mathrm{W}\right)$, the park covers an area of 611.55 hectares, of which about 400 ha are represented by semideciduous forest (SF) and 180 ha by savanna. According to Köppen's system the regional climate is Cwa, with two well defined seasons: dry winter and rainy summer (Bertoni et al., 2001).

The experiment was installed in an abandoned pasture of 10.75ha (Tabanez et al., 2003) located a minimum of $150 \mathrm{~m}$ from the savanna and $230 \mathrm{~m}$ from the forest edges. Although still dominated by exotic grasses, sparse trees and shrubs naturally developed in the area, among which are: Baccharis dracunculifolia DC. (Asteraceae), Byrsonima intermedia (Malpighiaceae), Myrsine coriacea (Primulaceae), Zanthoxylum rhoifolium (Rutaceae), Solanum spp. (Solanaceae), Trema micrantha (Cannabaceae) and Aegyphila sellowiana (Lamiaceae).

\subsection{Procedures}

For the evaluation of seed deposition, traps were installed in four experimental models: a) under natural perches (NPs); b) under simple artificial perches (SAPs); c) under elaborate artificial perches (EAPs) and d) in a control area (CA). In each sample set were allocated 10 seed traps, totaling 40 units. Traps were made of wood and PP-NWF (polypropylene non-woven-fabric), positioning the tissue about $30 \mathrm{~cm}$ from the ground to reduce the chances of seed predation by terrestrial invertebrates as well as the conditions for its germination, as suggested by Bocchese et al. (2008).

SAPs consisted of a $3 \mathrm{~m}$ tall bamboo and a crossbar $1 \mathrm{~m}$ long attached perpendicularly at the top; EAPs were built with Eucalyptus logs $7 \mathrm{~m}$ tall and 3 crossbars $1 \mathrm{~m}$ long, 1,5 $\mathrm{m}$ distant from each other counting from the top. The arrangement of artificial perches in the field is shown in Figure 1. NPs corresponded to 5 trees naturally developed in the abandoned pasture, randomly chosen, located around the set of artificial perches. Under the canopy of each tree were installed two seed traps. For the $\mathrm{CA}$, traps were installed in the open field, adjacent to the artificial perches, according to Figure 1.

\section{Module 1: Control area}
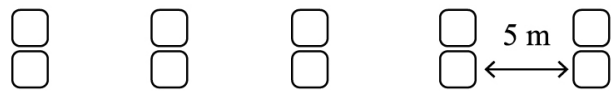

Module 2: Elaborate artificial perches

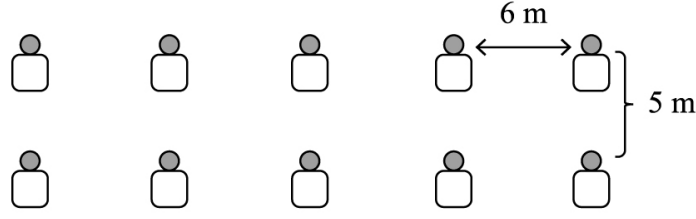

Module 3: Simple artificial perches

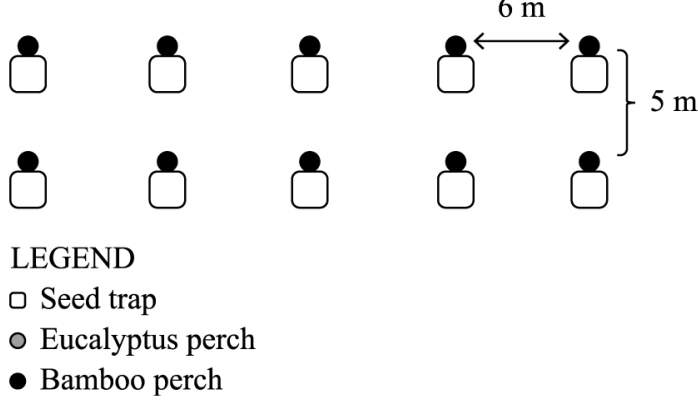

Figure 1. Arrangement of artificial perches and seed traps in the experimental area. 
This experiment was conducted between June 2012 and May 2013. Traps were emptied at intervals of 20 days (except when it was necessary to fix the seed traps: between August 20 and August 30, 2012; October 10 and October 19, 2012; December 19, 2012, and January 15, 2013). Seeds were sorted, counted and identified by comparison with the surrounding fertile material and consulting specific bibliography (Lorenzi, 2008, 2009a, b; Kuhlmann, 2012). Only bird-dispersed seeds were considered; unidentified species were classified as morphospecies, according to Melo et al. (2000).

Plant species were ecologically classified according to: a) origin: native or exotic; and b) ecological group: pioneer, early secondary and late secondary. The climax species category was not included in successional classes because many typical understory plants occur in both stages, more mature and other succession phases, according to Gandolfi et al. (1995). The inclusion of species in ecological groups followed descriptions of Batalha and Mantovani (2001), Paula et al. (2004), Pinheiro and Monteiro (2009) and field observations. Scientific nomenclature and family classification follow the Reflora (2014).

The use of artificial perches by birds was also evaluated during one year, allowing recording the main visitor species and seasonal variations (Holl, 1998). Visits were recorded for $120 \mathrm{~h}$, being $10 \mathrm{~h}$ of monthly observations, using $8 \mathrm{x} 40 \mathrm{~mm}$ binoculars, from places where it was possible to view the SAPs and EAPs at the same time. Natural perches were not included in the systematic observations due to the impossibility to visualize all of them at the same time, invalidating data comparison. Recorded species were grouped into feeding guilds, according to Sick (1997) and field observations. Taxonomic classification follows the Brazilian Ornithological Records Committee (CBRO, 2014).

\subsection{Data analysis}

The Spearman Correlation test was used to evaluate the degree of association between seed deposition and rainfall (data from Pirassununga region obtained in Tabanez et al., 2003) and between seed rain and records on perches. The Kruskal-Wallis test was performed to verify whether there was a significant variation in seed deposition among treatments. And the Mann-Whitney U test was used to determine whether there was significant difference between the rates of visitation by birds on artificial perches. All analyzes were performed using the statistical package BioEstat 5.0 (Ayres et al., 2007).

\section{Results}

\subsection{Seed deposition}

In one year, a total of 23,911 seeds was recorded: $74(0.3 \%)$ in the CA, $1,642(6.9 \%)$ under the SAPs, $5,816(24.3 \%)$ under the EAPs and 16,379 (68.5\%) under the NPs. The difference in seed deposition between the models was highly significant (Kruskal-Wallis $\mathrm{H}=35.65$, $\mathrm{p}<0.0001$ ). Seeds of 70 bird-dispersed species belonging to 32 families were collected, of which eight were not identified. The species richness recorded in each experimental model was as follows: five species $(7.1 \%)$ in the CA, 21 species (30.0\%) under the SAPs, 37 species (52.9\%) under EAPs and 60 species $(85.7 \%)$ under the NPs (Table 1).

The most representative families in number of species were: Myrtaceae, with six species, followed by Melastomataceae and Rubiaceae, with five species each (Table 1). The species that showed greater seed amounts were, in decrescent order: Miconia affinis $(41.0 \%, \mathrm{n}=9,799)$, Callicarpa reevesii $(17.3 \%, \mathrm{n}=4,134)$, Solanum $\mathrm{sp}$. $3(13.4 \%, \mathrm{n}=3,215)$, Myrsine coriacea $(10.6 \%, \mathrm{n}=2,530)$ and Cecropia pachystachya $(6.7 \%, \mathrm{n}=1,597)$, totalizing $89 \%$ of recorded seeds. Most of the recorded species belongs to the group of early secondary $(40.5 \%, \mathrm{n}=17)$, followed by pioneers $(35.7 \%, \mathrm{n}=15)$ and, finally, by late secondary $(16.7 \%, \mathrm{n}=7)$ (Table 1$)$.

There was a positive correlation between the average of monthly rainfall and monthly seed deposition (Spearman Correlation test: $\left.r_{s}=0.61, p=0.047\right)$. The highest number of seeds was recorded between November and March, with dispersal peak in the second half of February ( $n=5,304$ seeds), while the lowest total amount was recorded in September $(\mathrm{n}=184)$ as shown in Figure 2.

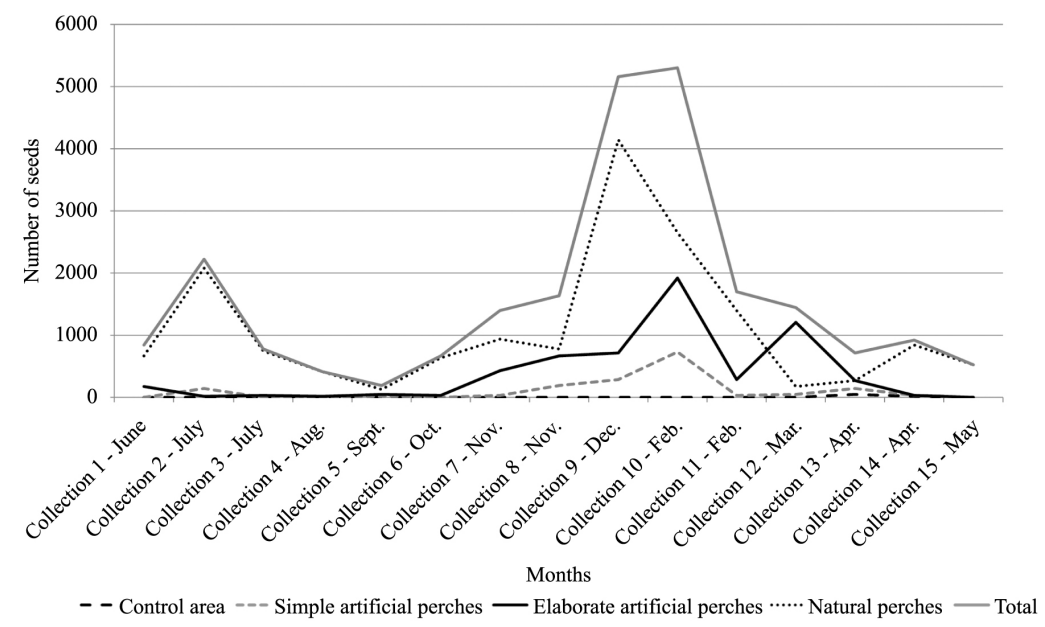

Figure 2. Number of bird-dispersed seeds monthly collected in each experimental model between June 2012 and May 2013. 
Table 1. Bird-dispersed species with seeds recorded in the traps followed between June 2012 and May 2013, followed by ecological and quantitative data.

\begin{tabular}{|c|c|c|c|c|c|c|c|}
\hline \multirow{2}{*}{ Family/Species } & \multirow{2}{*}{$\mathbf{E G}^{1}$} & \multirow{2}{*}{$\mathbf{O}^{2}$} & \multicolumn{5}{|c|}{ Number of seeds ${ }^{3}$} \\
\hline & & & $\mathbf{C A}$ & SAPs & EAPs & NPs & Total \\
\hline \multicolumn{8}{|l|}{ Anacardiaceae } \\
\hline Tapirira guianensis Aubl.\# & $\mathrm{P}$ & $\mathrm{da} / \mathrm{s} / \mathrm{sf}$ & - & - & 5 & 29 & 34 \\
\hline \multicolumn{8}{|l|}{ Annonaceae } \\
\hline Annona emarginata (Schltdl.) H.Rainer & $\mathrm{P}$ & - & - & - & 1 & 1 & 2 \\
\hline Annona sp. & - & - & - & 1 & - & - & 1 \\
\hline Xylopia aromatica (Lam.) Mart.\# & $\mathrm{P}$ & $\mathrm{da} / \mathrm{s}$ & - & 38 & 65 & 19 & 122 \\
\hline \multicolumn{8}{|l|}{ Araliaceae } \\
\hline Schefflera morototoni (Aubl.) Maguire et al." & IS & $\mathrm{da} / \mathrm{s} / \mathrm{sf}$ & - & - & 38 & 64 & 102 \\
\hline \multicolumn{8}{|l|}{ Arecaceae } \\
\hline Euterpe edulis Mart. & LS & sf & - & - & 1 & 2 & 3 \\
\hline Syagrus romanzoffiana (Cham.)Glassman ${ }^{\#}$ & IS & $\mathrm{s} / \mathrm{sf}$ & - & - & - & 13 & 13 \\
\hline \multicolumn{8}{|l|}{ Cannabaceae } \\
\hline Trema micrantha (L.) Blume ${ }^{\#}$ & $\mathrm{P}$ & $\mathrm{da} / \mathrm{sf}$ & - & - & 3 & 16 & 19 \\
\hline \multicolumn{8}{|l|}{ Dilleniaceae } \\
\hline Davilla elliptica A.St.-Hil. & $\mathrm{U}$ & $\mathrm{s}$ & - & - & - & 1 & 1 \\
\hline \multicolumn{8}{|l|}{ Euphorbiaceae } \\
\hline Alchornea glandulosa Poepp. \& Endl $\#$ & IS & $\mathrm{da} / \mathrm{s} / \mathrm{sf}$ & - & - & 5 & 14 & 19 \\
\hline Maprounea guianensis Aubl. & IS & $\mathrm{s}$ & - & 4 & - & 30 & 34 \\
\hline \multicolumn{8}{|l|}{ Lacistemataceae } \\
\hline Lacistema hasslerianum Chodat.\# & LS & $\mathrm{s}$ & - & 3 & 3 & 27 & 33 \\
\hline \multicolumn{8}{|l|}{ Lamiaceae } \\
\hline Aegiphila sellowiana Cham.\# & $\mathrm{P}$ & $\mathrm{da} / \mathrm{s}$ & - & 8 & 31 & 14 & 53 \\
\hline \multicolumn{8}{|l|}{ Lauraceae } \\
\hline Ocotea corymbosa (Meisn.) Mez & LS & $\mathrm{s} / \mathrm{sf}$ & - & 21 & 50 & 25 & 96 \\
\hline Ocotea pulchella (Nees \& Mart.) Mez & IS & $\mathrm{s} / \mathrm{sf}$ & - & - & 1 & - & 1 \\
\hline \multicolumn{8}{|l|}{ Malpighiaceae } \\
\hline Byrsonima intermedia A.Juss ${ }^{\#}$ & $\mathrm{P}$ & $\mathrm{da} / \mathrm{s}$ & 13 & 50 & 89 & 8 & 160 \\
\hline \multicolumn{8}{|l|}{ Melastomataceae } \\
\hline Miconia affinis DC.\# & IS & $\mathrm{da} / \mathrm{s} / \mathrm{sf}$ & 1 & 933 & 2658 & 6207 & 9799 \\
\hline Miconia albicans (Sw.) Triana ${ }^{\#}$ & IS & $\mathrm{s}$ & - & - & - & 119 & 119 \\
\hline Miconia sp. & - & - & - & - & 3 & 2 & 5 \\
\hline Melastomataceae 1 & - & - & - & - & - & 3 & 3 \\
\hline Melastomataceae 2 & - & - & - & - & - & 3 & 3 \\
\hline \multicolumn{8}{|l|}{ Meliaceae } \\
\hline Guarea guidonia (L.) Sleumer\# & LS & $\mathrm{s} / \mathrm{sf}$ & - & 1 & 4 & - & 5 \\
\hline Trichilia pallida Sw.\# & IS & $\mathrm{da} / \mathrm{s} / \mathrm{sf}$ & - & - & - & 14 & 14 \\
\hline Trichilia $\mathrm{sp}$ & - & & - & 1 & - & - & 1 \\
\hline \multicolumn{8}{|l|}{ Moraceae } \\
\hline Ficus citrifolia Mill. & IS & $\mathrm{s}$ & - & 1 & - & 216 & 217 \\
\hline Ficus sp. & - & - & - & - & - & 16 & 16 \\
\hline Maclura tinctoria (L.) D.Don ex Steud. & IS & sf & - & - & 1 & 44 & 45 \\
\hline \multicolumn{8}{|l|}{ Myristicaceae } \\
\hline Virola sebifera Aubl." & IS & $\mathrm{s}$ & - & - & 2 & 1 & 3 \\
\hline \multicolumn{8}{|l|}{ Myrtaceae } \\
\hline Eugenia florida DC.\# & LS & $\mathrm{da} / \mathrm{sf}$ & - & 2 & 4 & 6 & 12 \\
\hline Myrcia sp..\# & - & $\mathrm{da}$ & - & - & - & 7 & 7 \\
\hline
\end{tabular}

${ }^{1}$ Ecological group; P: pioneer, IS: initial secondary, LS: late secondary, U: unrated. ${ }^{2}$ Occurrence; s: savanna, sf: Semidecidous Forest, da: disturbed areas (according Tabanez et al., 2003 and field observations). ${ }^{3}$ Number of seeds recorded in each experimental model, being SAPs: simple artificial perches, EAPs: elaborate artificial perches, NP: natural perches and CA: control area. *Exotic species. \#indicates that at least one individual of the species was observed in the experiment surroundings. 
Table 1. Continued...

\begin{tabular}{|c|c|c|c|c|c|c|c|}
\hline \multirow{2}{*}{ Family/Species } & \multirow{2}{*}{$\mathbf{E G}^{1}$} & \multirow{2}{*}{$\mathbf{O}^{2}$} & \multicolumn{5}{|c|}{ Number of seeds ${ }^{3}$} \\
\hline & & & CA & SAPs & EAPs & NPs & Total \\
\hline Psidium guajava L.\# & $\mathrm{P}$ & da & - & - & 53 & 49 & 102 \\
\hline Psidium sp.1 & - & - & - & - & 1 & - & 1 \\
\hline Psidium sp. 2 & - & - & - & - & - & 1 & 1 \\
\hline Myrtaceae 1 & - & - & - & - & - & 18 & 18 \\
\hline \multicolumn{8}{|l|}{ Piperaceae } \\
\hline Piper sp. & - & - & - & - & - & 47 & 47 \\
\hline \multicolumn{8}{|l|}{ Primulaceae } \\
\hline Myrsine coriacea (Ruiz \& Pav.) Mez & $\mathrm{P}$ & $\mathrm{da} / \mathrm{s}$ & 46 & 282 & 803 & 1399 & 2530 \\
\hline \multicolumn{8}{|l|}{ Rhamnaceae } \\
\hline Rhamnidium elaeocarpum Reissek $^{\#}$ & IS & $\mathrm{da} / \mathrm{sf}$ & - & - & - & 16 & 16 \\
\hline \multicolumn{8}{|l|}{ Rosaceae } \\
\hline Prunus sellowii Koehne & IS & $\mathrm{s}$ & - & 2 & 8 & 8 & 18 \\
\hline \multicolumn{8}{|l|}{ Rubiaceae } \\
\hline Amaioua guianensis Aubl. & IS & $\mathrm{s}$ & - & - & - & 2 & 2 \\
\hline Ixora gardneriana Benth. & LS & $\mathrm{s}$ & - & - & 2 & 16 & 18 \\
\hline Palicourea sp. & - & - & - & - & - & 2 & 2 \\
\hline Rubiaceae 1 & - & - & - & - & - & 1 & 1 \\
\hline Rubiaceae 2 & - & - & - & - & - & 2 & 2 \\
\hline \multicolumn{8}{|l|}{ Rutaceae } \\
\hline Zanthoxylum rhoifolium Lam.\# & $\mathrm{P}$ & $\mathrm{da} / \mathrm{s} / \mathrm{sf}$ & 13 & 21 & 33 & 79 & 146 \\
\hline \multicolumn{8}{|l|}{ Salicaceae } \\
\hline Casearia sylvestris Sw.\# & IS & $\mathrm{da} / \mathrm{s} / \mathrm{sf}$ & - & - & - & 10 & 10 \\
\hline \multicolumn{8}{|l|}{ Sapindaceae } \\
\hline Cupania vernalis Cambess. & IS & $\mathrm{s}$ & - & - & - & 1 & 1 \\
\hline \multicolumn{8}{|l|}{ Sapotaceae } \\
\hline $\begin{array}{l}\text { Chrysophyllum marginatum (Hook. \& Arn.) } \\
\text { Radlk. }\end{array}$ & LS & $\mathrm{s}$ & - & - & - & 2 & 2 \\
\hline \multicolumn{8}{|l|}{ Siparunaceae } \\
\hline Siparuna guianensis Aubl.\# & IS & $\mathrm{da} / \mathrm{s} / \mathrm{sf}$ & - & 16 & 20 & 97 & 133 \\
\hline \multicolumn{8}{|l|}{ Smilacaceae } \\
\hline Smilax fluminensis Steud." & $\mathrm{U}$ & s & - & - & - & 1 & 1 \\
\hline Smilax goyazana A.DC.\# & $\mathrm{U}$ & s & - & - & - & 16 & 16 \\
\hline \multicolumn{8}{|l|}{ Solanaceae } \\
\hline Solanum americanum Mill." & $\mathrm{P}$ & da & - & 49 & 83 & 545 & 677 \\
\hline Solanum sp. 1 & - & - & - & 4 & 14 & - & 18 \\
\hline Solanum sp. 2 & - & - & - & - & 9 & 58 & 67 \\
\hline Solanum sp. 3 & - & - & 1 & 47 & 512 & 2655 & 3215 \\
\hline \multicolumn{8}{|l|}{ Styracaceae } \\
\hline Styrax ferrugineus Nees \& Mart." & $\mathrm{P}$ & da & - & - & - & 2 & 2 \\
\hline Styrax sp. & - & - & - & - & - & 1 & 1 \\
\hline \multicolumn{8}{|l|}{ Urticaceae } \\
\hline Cecropia pachystachya Trécul ${ }^{\#}$ & $\mathrm{P}$ & $\mathrm{da} / \mathrm{s} / \mathrm{sf}$ & - & 32 & 1122 & 443 & 1597 \\
\hline Cecropia glaziovii Snethl.* & $\mathrm{P}$ & sf & - & - & 17 & 123 & 140 \\
\hline \multicolumn{8}{|l|}{ Verbenaceae } \\
\hline Callicarpa reevesii Wall.*\# & $\mathrm{P}$ & da & - & 126 & 170 & 3838 & 4134 \\
\hline Citharexylum myrianthum Cham. & $\mathrm{P}$ & - & - & - & 1 & - & 1 \\
\hline Vitaceae & & & & & & & \\
\hline
\end{tabular}


Table 1. Continued...

\begin{tabular}{|c|c|c|c|c|c|c|c|}
\hline \multirow{2}{*}{ Family/Species } & \multirow{2}{*}{$\mathbf{E G}^{1}$} & \multirow{2}{*}{$\mathbf{O}^{2}$} & \multicolumn{5}{|c|}{ Number of seeds ${ }^{3}$} \\
\hline & & & $\mathbf{C A}$ & SAPs & EAPs & NPs & Total \\
\hline Cissus sp.1 & - & - & - & - & 5 & - & 5 \\
\hline Cissus sp.2 & - & - & - & - & - & 1 & 1 \\
\hline \multicolumn{8}{|l|}{ Non identified } \\
\hline Morphospecies 1 & - & - & - & - & - & 2 & 2 \\
\hline Morphospecies 2 & - & - & - & - & - & 3 & 3 \\
\hline Morphospecies 3 & - & - & - & - & - & 13 & 13 \\
\hline Morphospecies 4 & - & - & - & - & - & 1 & 1 \\
\hline Morphospecies 5 & - & - & - & - & - & 24 & 24 \\
\hline Morphospecies 6 & - & - & - & - & 1 & 2 & 3 \\
\hline Morphospecies 7 & - & - & - & - & 2 & - & 2 \\
\hline Morphospecies 8 & - & - & - & - & 1 & - & 1 \\
\hline
\end{tabular}

${ }^{1}$ Ecological group; P: pioneer, IS: initial secondary, LS: late secondary, U: unrated. ${ }^{2}$ Occurrence; s: savanna, sf: Semidecidous Forest, da: disturbed areas (according Tabanez et al., 2003 and field observations). ${ }^{3}$ Number of seeds recorded in each experimental model, being SAPs: simple artificial perches, EAPs: elaborate artificial perches, NP: natural perches and CA: control area. *Exotic species. \#indicates that at least one individual of the species was observed in the experiment surroundings.

\subsection{Bird visitation to perches}

During 120 hours of focal observations, 21 bird species belonging to 14 families were recorded using artificial perches. There were 280 visits, of which $11.8 \%$ $(n=33)$ occurred on the SAPs and $88.2 \%(n=247)$ on the EAPs. Visitation rates differed significantly between the treatments: 0.3 visits/h on the SAPs and 2.1 visits/h on the EAPs (Mann-Whitney U test: $\mathrm{p}=0.006$ ). Tyrannidae was the most representative family in number of visitors and visitations, with 7 species $(33.3 \%)$ who used the perches in $60.0 \%$ of the visits $(\mathrm{n}=168)$. The species Tyrannus melancholicus made the highest number of visits $(28.2 \%$, $\mathrm{n}=79$ ), followed by Pitangus sulphuratus $(24.6 \%, \mathrm{n}=69)$, both from Tyrannidae family (Table 2).

There was temporal variation in the number of visits, with a positive correlation between rainfall and number of monthly visits (Spearman Correlation test: $r_{s}=0.76$, $\mathrm{p}=0.007$ ). During the rainy season occurred $81.8 \%$ of the visits, with a peak in February (26.8\% of the visits), while in the dry season occurred $18.9 \%$ of the visits (Figure 3 ).

The following migratory species were recorded using the perches: Myiodynastes maculatus, T. melancholicus, Tyrannus savana and Empidonomus varius, all from Tyrannidae family (Table 2). These species (except T. savana, recorded out of focal sessions) correspond to $14.3 \%$ of the total and were responsible for $34.3 \%$ of the visits, restricted to the period from September to March, coinciding with the period of greater visitation to perches.

The most representative feeding guilds were the omnivorous (38.1\%) and insectivores (38.1\%), followed by granivorous (14.4\%) and frugivorous (9.4\%). Although Patagioenas picazuro and Forpus xanthopterygius are classified as frugivorous, some authors consider them as seed predators (Howe and Estabrook, 1977; Moermond and Denslow, 1985). However, $42.9 \%$ of the species recorded include fruits in the diet at least during scarcity of its preferential food. These potentially disperser birds were responsible for $64.3 \%$ of the visits (Table 2).

\section{Discussion}

\subsection{Seed deposition}

Perches increased the seed deposition in the old pasture as observed in other studies developed in temperate and tropical areas (McDonnell and Stiles, 1983; McClanahan and Wolfe, 1993; Wunderle, 1997; Holl, 1998; Shiels and Walker, 2003; Zanini and Ganade, 2005; Carlo and Yang, 2011; Cavallero et al., 2013).

According to Wunderle (1997) and Jordano et al. (2006), seed deposition can be significantly higher under perches than in nearby places where there are no perching sites, as in the control area of this study, because birds regurgitate and defecate more when perching than during flight. In the same way, perches with more crossbars or branches are more likely to be visited (Guevara and Laborde, 1993; Wunderle, 1997; Holl, 1998; Zanini and Ganade, 2005).

Furthermore, the natural perches used in the PFSP offered additional resources for birds such as fruits, insects and shelter, which also seems to have contributed to the greater seed deposition in their traps. On artificial perches birds became more exposed, besides not having food readily available, which probably inhibited the visitation by some species sporadically observed on natural perches, as the tanagers Ramphocelus carbo (Pallas, 1764), Tangara sayaca (Linnaeus, 1766), Tangara cayana (Linnaeus, 1766 ) and Dacnis cayana (Linnaeus, 1766), among others. According to Zahawi et al. (2012), the structural complexity of perches is an important factor for attracting bird-seed dispersers in degraded areas, since it is directly related to the availability of food resources and habitats.

Only five plant species were responsible for almost $90 \%$ of the seed deposition. These species are characterized by a generalist dispersal system, since they produce large amounts of small, colorful and juicy fruits, attracting a wide variety of opportunistic birds. Dispersal of these plants is highly efficient near forest edges and secondary vegetation, where they usually occur (Snow, 1981; Howe 
Athiê, S. and Dias, M.M.

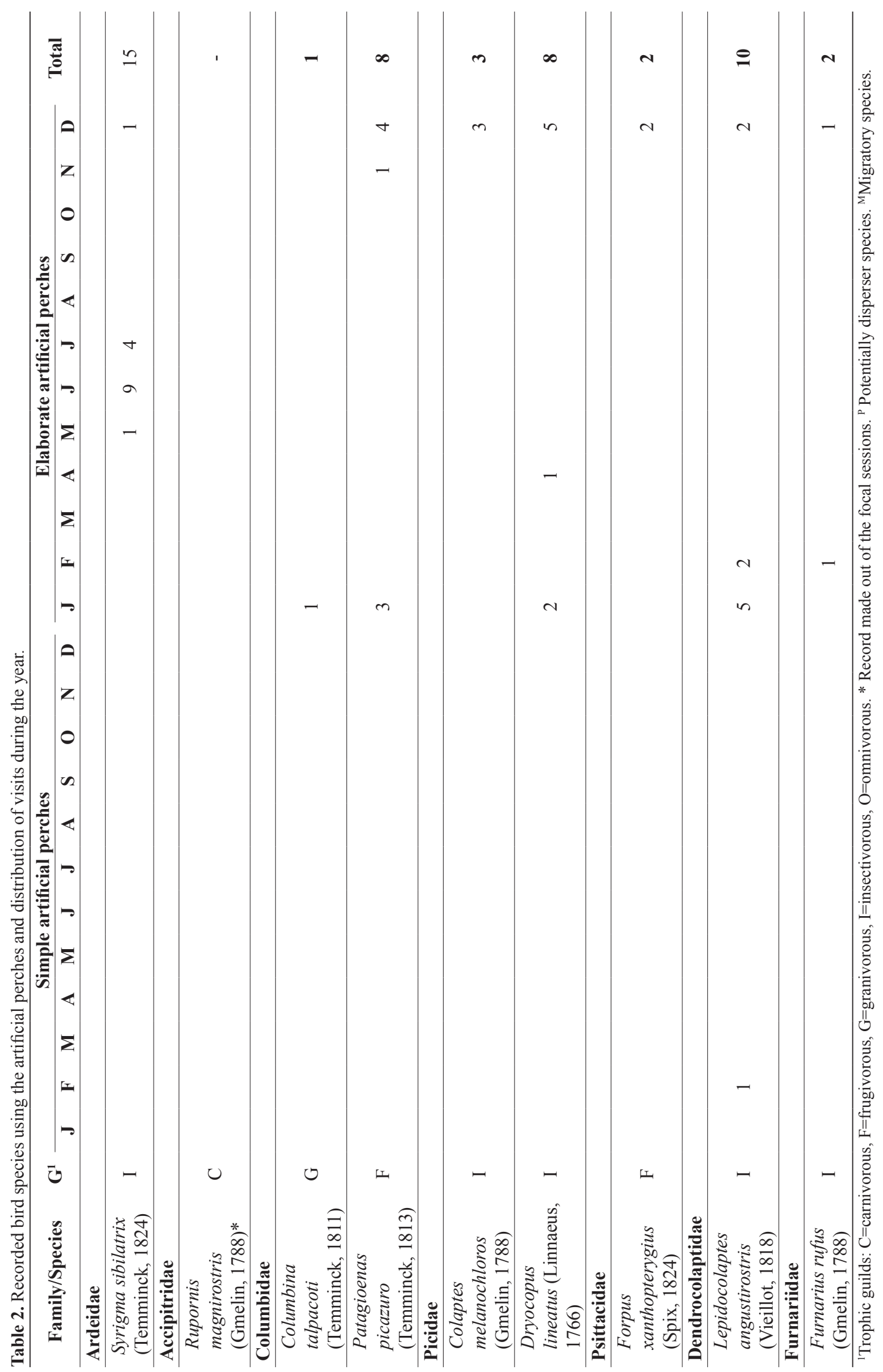

86

Braz. J. Biol., 2016, vol. 76, no. 1, pp. 80-92 


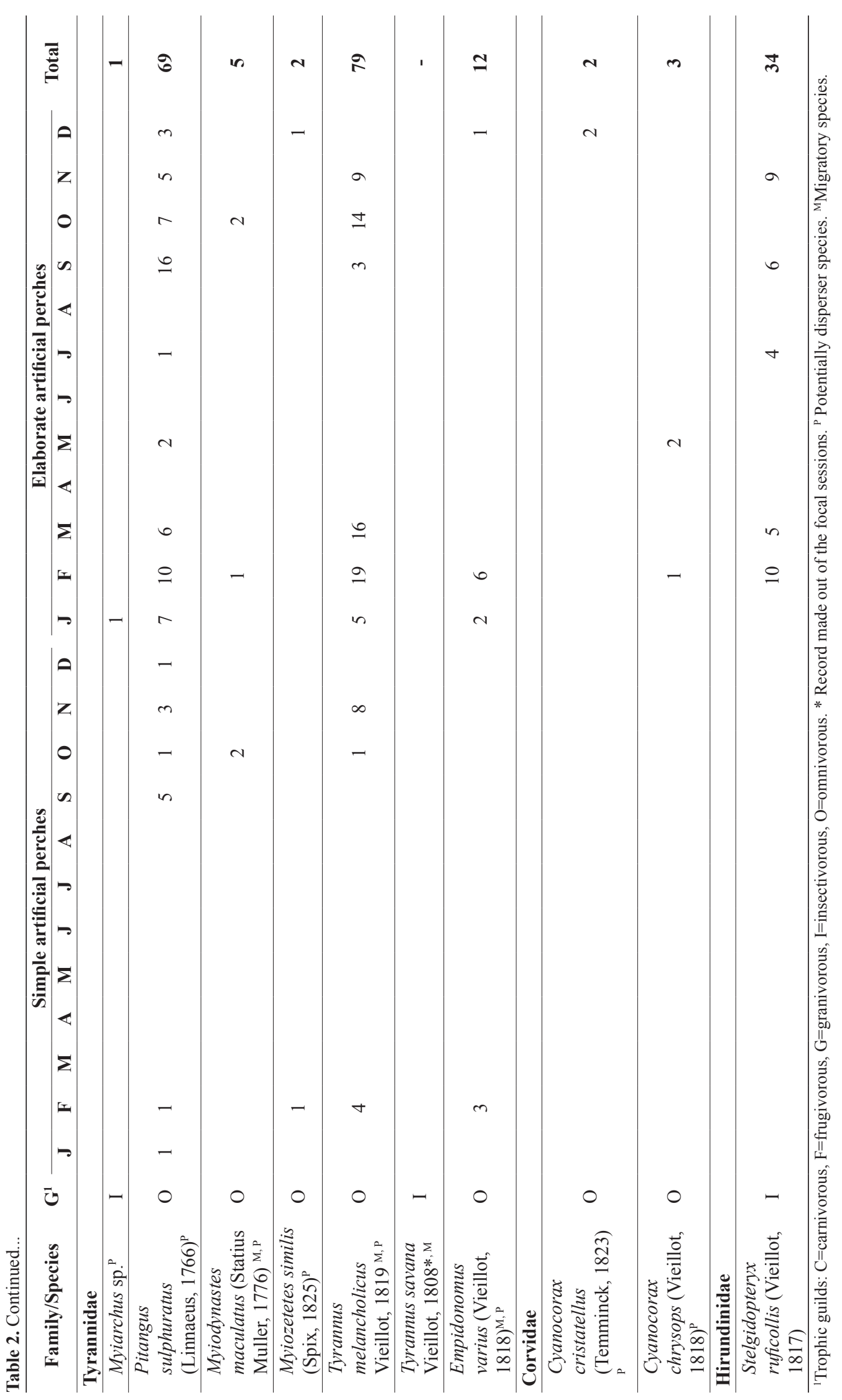


Athiê, S. and Dias, M.M.

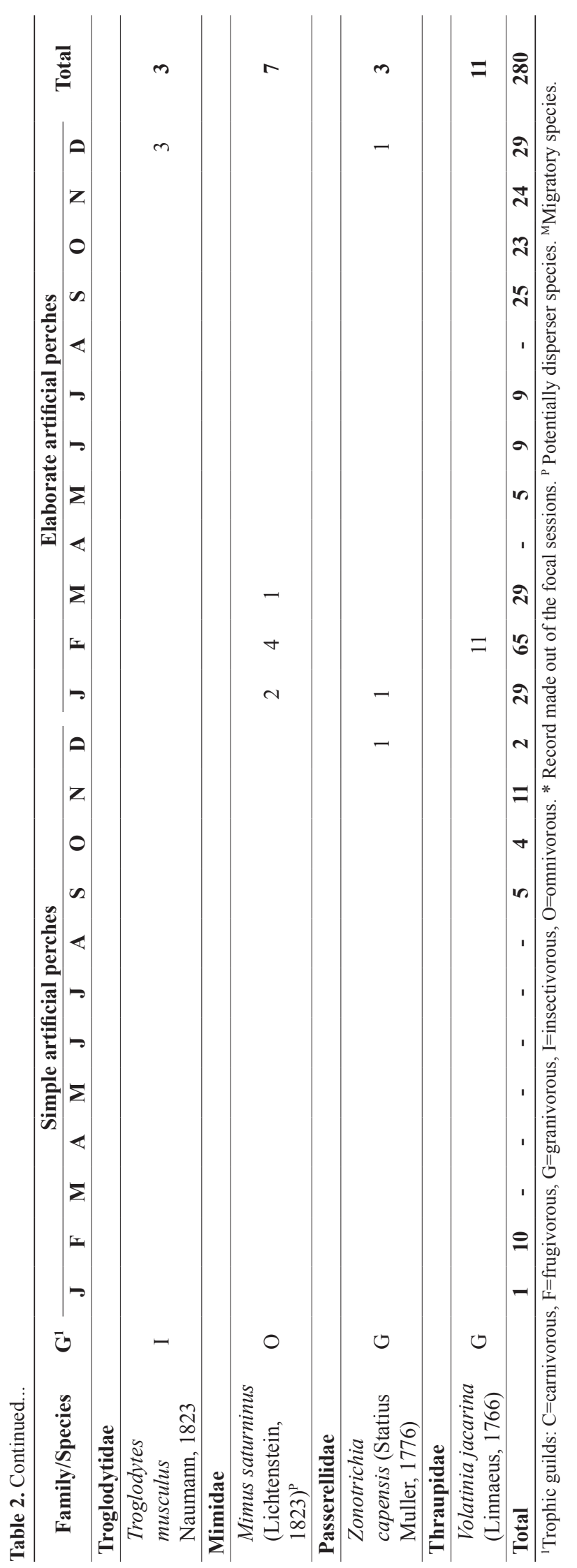




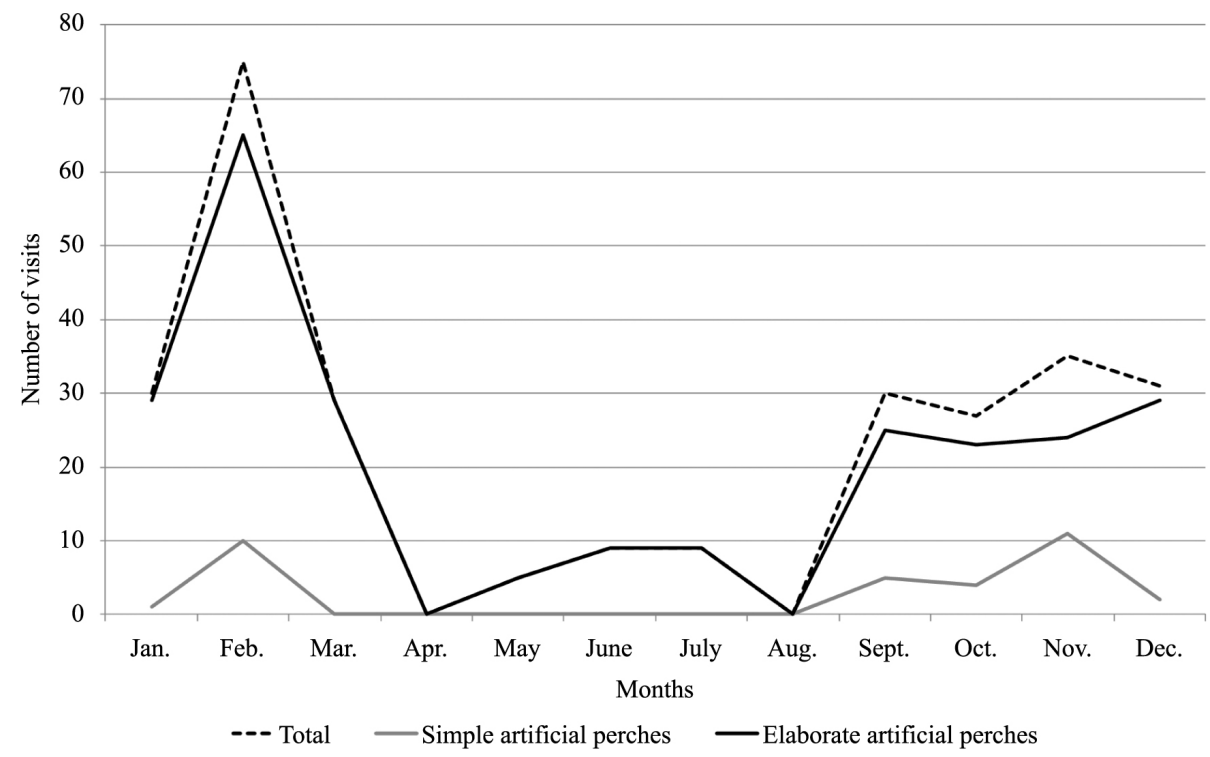

Figure 3. Temporal variation in the number of bird visits to the artificial perches during a 12-month period.

and Smallwood, 1982; Fleming et al., 1987; Zahawi et al., 2012).

M. affinis, species with the highest rate of seed deposition, belongs to the family Melastomataceae, considered one of the most attractive to birds in the New World. These plants have quite small fruits with a high proportion of pulp, bearing a large number of small seeds (Snow, 1981). It is one of the most abundant bird-dispersed species in the PFSP (pers. obs.)

The second species with the highest deposition rate was the exotic Callicarpa reevesii, originating from China (Potascheff et al., 2010). Similar results were obtained by Athiê and Dias (2012) in a study of frugivory by birds in a reforestation area in Rio Claro, São Paulo State. The authors found that the species with the highest visitation rates and consumption by birds was the exotic Melia azedarach L. (Meliaceae), which produced fruits during all dry season, as well as C. reevesii. For Gosper et al. (2005), invasive alien plants usually bear fruit in times of food scarcity to reduce competition for dispersers with native species, thus facilitating its propagation and colonization of new sites. However, in the PFSP only two individuals of $C$. reevesii were observed, which does not corroborate the hypothesis that it acts as invasive species.

In all experimental models were predominant, in richness and number of seeds, pioneer and secondary initial species. These results reflect the regeneration stage of vegetation and the floristic composition of surroundings: vegetation nearest perches is mainly composed of early successional plants, common at forest edges and in areas in natural regeneration process, including the old pasture.

Equally important is the effect of distance between perches and surrounding remnants, the main seed sources of late secondary species to the old pasture. Most of bird-dispersed seeds is dropped in less than 100m away from the parent plant (Wunderle, 1997), thus patterns of dispersal distance per animal (seed shadow) are typically a blend of high dispersal frequency near the maternal plant and a low occurrence of these events over long distances (Jordano et al., 2006; Jordano, 2014). Knowing the minimum distances between the perches and the remnants of savanna and SF in PFSP are, respectively, 150 and 230m (see Material and Methods), these findings help to explain the low frequency of seeds from later stage species in the experiment.

At the same time, disperser birds visiting abandoned pasture and other disturbed areas, often explore few or no resources in forest interior, where those plant species are more frequent, even when these areas are surrounded by remaining forests (Holl, 1998). Thus, forest species such as the Euterpe edulis palm, had low relative abundance in the seed traps. On the other hand, species from early ecological groups are essential for the natural regeneration process because they can act as "facilitators", helping the establishment of later stages species in the recovery area (Avendaño-Yáñez et al., 2014). Moreover, they are indispensible for attracting and/or maintaining pollinators and seed dispersers, because in general they produce large amounts of flowers and fruits attractive to animals (Tomazi et al., 2010).

Regarding temporal patterns of dispersal, the seed deposition was higher in the rainy season. In the tropics, animal-seed dispersal is more common during wet season, relating to pattern of plant fruiting (Howe and Smallwood, 1982; Fleming et al., 1987; Wunderle, 1997; Zanini and Ganade, 2005). The peak of seed deposition occurred between December and February, coinciding too with birds breeding season, when increases the exploitation of food resources (Pizo, 1997; Jordano, 2014). 


\subsection{Bird visitation to perches}

The species observed using artificial perches are typically generalists. This result was expected, since most of birds that frequent disturbed areas have opportunistic habits, with diet based on insects and fruits of pioneer and ruderal plants, common in forest edges and secondary environments (Guedes et al., 1997; Jordano et al., 2006). Similar result was found by Holl (1998), while evaluating seed deposition by birds under artificial perches in an abandoned pasture in Costa Rica. According to this author, who also developed the work in a field surrounded by native vegetation, forest bird species did not visit perches because they are not used to exploiting resources in open areas and usually find the necessary resources for their own survival inside forest.

On the other hand, regeneration process does not necessarily depend on specialized, large and medium-sized frugivores, often absent in areas to be restored. Bird-seed dispersers that can tolerate disturbed landscapes are the most important in the early stages of forest succession, since they are responsible for disseminating propagules that will begin this process (Guedes et al., 1997; Jordano et al., 2006; Francisco et al., 2007).

McKey (1975) and Bocchese et al. (2008) emphasize the importance of Tyrannidae, the most representative family in this study, for the forest succession: these birds feed both in forest edges and secondary and isolated plants. While feeding on insects in open areas, where they can find and capture them more easily, they carry seeds from pioneer species to degraded areas, accelerating the natural regeneration. In fact, many flycatchers were observed capturing preys in flight, while they were using the artificial perches of this experiment.

According to Bocchese et al. (2008), perches, besides providing better airspace visibility for birds that capture insects in flight, such as flycatchers, improve the field of view of potential predators. These authors observed in an experiment with artificial perches, near a savanna remnant in Mato Grosso do Sul, that some birds used them for hunting and foraging. In the PFSP experiment, bones of small animals were found in seed traps under the SAPs, possibly leftover food of predatory birds such as owls, hawks or falcons. For McDonnell (1986), perches higher than the surrounding vegetation, such as the elaborate perches of this experiment, are attractive to predatory birds because it act as an observatory for these species.

There was a seasonal pattern in bird visits to the perches, intensified during the rainy season. In this period, in addition to having the increase of resources exploitation due to greater availability of fruits and reproductive activity in birds, there is also the arrival of migratory birds, many of which participate actively of seed dispersal (Pizo, 1997; Alves et al., 2008; Zahawi et al., 2012). Zanini and Ganade (2005) obtained similar results in a study about efficiency of perches in restoring Araucaria Forests in Brazil. According to Jordano (2014) the fruit ripening of some bird-dispersed plants is synchronized to the arrival of migrant birds.

\section{Final Considerations}

The present study demonstrated that perches - especially the NPs and EAPs - increased significantly seed deposition by birds in the abandoned pasture. However, of the more these areas are dominated by exotic grasses, is important to make the control of weeds, allowing germination of dispersed seeds in the area as well as the appropriate development of seedlings.

Considering the ecological efficiency in attracting bird-seed dispersers and increasing of propagules deposition in open areas, as well as the low cost to install and maintain it, the use of perches for birds becomes recommended in similar conditions to those described in this study. In areas relatively distant from a seed source, is necessary to combine or replace this method by other forest restoration techniques.

\section{Acknowledgements}

The authors are grateful to CAPES for the scholarship granted to the first author. We also thank the Forest Institute for allowing the study in one of its protected areas, the Post-graduate Program in Ecology and Natural Resources of UFSCar (São Carlos Federal University), employees of the Porto Ferreira State Park and Vagner Reviere Jr. for helping with installation and maintenance of the experiment.

\section{References}

ALVES, M.A.S., RITTER, P.D., ANTONINI, R.D. and ALMEIDA, E.M., 2008. Two thrush species as dispersers of Miconia prasina (Sw.) DC. (Melastomataceae): an experimental approach. Brazilian Journal of Biology $=$ Revista Brasileira de Biologia, vol. 68, no. 2, pp. 397-401. http://dx.doi.org/10.1590/ S1519-69842008000200023. PMid:18660970.

ATHIÊ, S. and DIAS, M.M., 2012. Frugivoria por aves em um mosaico de Floresta Estacional Semidecidual e reflorestamento misto em Rio Claro, São Paulo, Brasil. Acta Botanica Brasílica, vol. 26 , no. 1 , pp. $84-93$. http://dx.doi.org/10.1590/S010233062012000100010.

AVENDAÑO-YÁÑEZ, M.L., SÁNCHEZ-VELÁSQUEZ, L.R., MEAVE, J.A. and PINEDA-LÓPEZ, M.R., 2014. Is facilitation a promising strategy for cloud forest restoration? Forest Ecology and Management, vol. 329, pp. 328-333. http://dx.doi.org/10.1016/j. foreco.2014.01.051

AYRES, M., AYRES-JUNIOR, M., AYRES, D.L. and SANTOS, A.A.S., 2007. Software BioEstat: aplicações estatísticas nas áreas das Ciências Biológicas e Médicas. Version 5.0 [software]. Belém: Sociedade Civil Mamirauá

BATALHA, M.A. and MANTOVANI, W., 2001. Floristic composition of the cerrado in the Pé-de-Gigante Reserve (Santa Rita do Passa Quatro, Southeastern Brazil). Acta Botanica Brasílica, vol. 15, no. 3, pp. 289-304. http://dx.doi.org/10.1590/ S0102-33062001000300001.

BERTONI, J.E.A., TOLEDO FILHO, D.V., LEITÃO FILHO, H.F., FRANCO, G.A.D.C. and AGUIAR, O.T., 2001. Flora arbórea e arbustiva do cerrado do Parque Estadual de Porto Ferreira (SP). Revista do Instituto Florestal, vol. 13, no. 2, pp. 169-188. 
BOCCHESE, R.A., OLIVEIRA, A.K.M., FAVERO, S., GARNÉS, S.J.S. and LAURA, V.A., 2008. Chuva de sementes e estabelecimento de plântulas a partir da utilização de árvores isoladas e poleiros artificiais por aves dispersoras de sementes, em área de Cerrado, Mato Grosso do Sul, Brasil. Revista Brasileira de Ornitologia, vol. 16 , no. 3, pp. 207-213.

CARLO, T.A. and YANG, S., 2011. Network models of frugivory and seed dispersal: challenges and opportunities. Acta Oecologica, vol. 37, no. 6, pp. 619-624. http://dx.doi.org/10.1016/j. actao.2011.08.001.

CAVALLERO, L., RAFFAELE, E. and AIZEN, M.A., 2013. Birds as mediators of passive restoration during early post-fire recovery. Biological Conservation, vol. 158, pp. 342-350. http:// dx.doi.org/10.1016/j.biocon.2012.10.004.

Comitê Brasileiro de Registros Ornitológicos - CBRO, 2014 [viewed 09 June 2014]. List of brazilian birds [online]. Available from: http://www.taxeus.com.br/lista/2582.

FLEMING, T.H., BREITWISCH, R. and WHITESIDES, G.H., 1987. Patterns of tropical vertebrate frugivore diversity. Annual Review of Ecology and Systematics, vol. 18, no. 1, pp. 91-109. http://dx.doi.org/10.1146/annurev.es.18.110187.000515.

FRANCISCO, M.R., LUNARDI, V.O. and GALETTI, M., 2007. Características dos propágulos, atributos das aves, e a dispersão das sementes de Pera glabrata (Schott, 1858) (Euphorbiaceae) numa área degradada de cerrado. Brazilian Journal of Biology = Revista Brasileira de Biologia, vol. 67, no. 4, pp. 627-634. http:// dx.doi.org/10.1590/S1519-69842007000400006.

GANDOLFI, S., LEITÃO FILHO, H.F. and BEZERRA, C.L.F., 1995. Estudo florístico e caráter sucessional das espécies arbustivoarbóreas de uma floresta mesófila semidecidual no município de Guarulhos, SP. Rev. Brasil. Biol. =. Brazilian Journal of Biology = Revista Brasileira de Biologia, vol. 55, no. 4, pp. 753-767.

GOSPER, C.R., STANSBURY, C.D. and VIVIAN-SMITH, G., 2005. Seed dispersal of fleshy-fruited invasive plants by birds: contributing factors and management options. Diversity \& Distributions, vol. 11 , no. 6, pp. 549-558. http://dx.doi. org/10.1111/j.1366-9516.2005.00195.x.

GRAHAM, L.L.B. and PAGE, S.E., 2012. Artificial bird perches for the regeneration of degraded tropical peat swamp forest: a restoration tool with limited potential. Restoration Ecology, vol. 20, pp. 631-637.

GUEDES, M.C., MELO, V.A. and GRIFFITH, J.J., 1997. Uso de poleiros artificiais e ilhas de vegetação por aves dispersoras de sementes. Ararajuba, vol. 5, no. 2, pp. 229-232.

GUEVARA, S. and LABORDE, J., 1993. Monitoring seed dispersal at isolated standing trees in tropical pastures: consequences for local species availability. Vegetatio, vol. 107/108, pp. 319-338.

HOLL, K.D., 1998. Do bird perching structures elevate seed rain and seedling establishment in abandoned tropical pasture? Ecological Research, vol. 6, no. 3, pp. 253-261. http://dx.doi. org/10.1046/j.1526-100X.1998.00638.x.

HOLL, K.D., LOIK, M.E., LIN, E.H.V. and SAMUELS, I.A., 2000. Tropical montane forest restoration in Costa Rica: overcoming barriers to dispersal and establishment. Restoration Ecology, vol. 8, no. 4, pp. 339-349. http://dx.doi.org/10.1046/j.1526100x.2000.80049.x.

HOOPER, E., LEGENDRE, P. and CONDIT, R., 2005. Barriers to forest regeneration of deforested and abandoned land in Panama. Journal of Applied Ecology, vol. 42, no. 6, pp. 1165-1174. http:// dx.doi.org/10.1111/j.1365-2664.2005.01106.x.
HOWE, H.F. and ESTABROOK, G.F., 1977. On the intraespecific competition for avian dispersers in tropical trees. American Naturalist, vol. 111, no. 981, pp. 817-832. http://dx.doi.org/10.1086/283216.

HOWE, H.F. and SMALLWOOD, J., 1982. Ecology of seed dispersal. Annual Review of Ecology and Systematics, vol. 13, no. 1, pp. 201-228. http://dx.doi.org/10.1146/annurev.es.13.110182.001221.

HOWE, H.F. and MIRITI, M.N., 2004. When seed dispersal matters. Bioscience, vol. 54, no. 7, pp. 651-660. http://dx.doi. org/10.1641/0006-3568(2004)054[0651:WSDM]2.0.CO;2.

JORDANO, P.M., GALETTI, M., PIZO, M.A. and SILVA, W.R., 2006. Ligando frugivoria e dispersão de sementes à biologia da conservação. In: C.F. DUARTE, H.G. BERGALLO, M.A. SANTOS and A.E. VA, eds. Biologia da conservação: essências. São Paulo: Editorial Rima, pp. 411-436.

JORDANO, P.M., 2014. Fruits and frugivory. In: R.S. GALLAGHER, ed. Seeds: the ecology of regeneration in plant communities. 3rd ed. Wallingford: Commonwealth Agricultural Bureau International, pp. 18-61.

KUHLMANN, M., 2012. Frutos e sementes do cerrado atrativos para fauna: guia de campo. Brasília: Rede de Sementes do Cerrado. 360 p.

LORENZI, H., 2008. Árvores brasileiras: manual de identificação e cultivo de plantas arbóreas nativas do Brasil. 5th ed. Nova Odessa: Instituto Plantarum. vol. 1, 384 p.

LORENZI, H., 2009a. Árvores brasileiras: manual de identificação e cultivo de plantas arbóreas nativas do Brasil. 3rd ed. Nova Odessa: Instituto Plantarum. vol. 2, 384 p.

LORENZI, H., 2009b. Árvores brasileiras: manual de identificação e cultivo de plantas arbóreas nativas do Brasil. Nova Odessa: Instituto Plantarum. vol. 3, $384 \mathrm{p}$.

MCCLANAHAN, T.R. and WOLFE, R.W., 1993. Accelerating forest succession in a fragmented landscape: the role of birds and perches. Conservation Biology, vol. 7, no. 2, pp. 279-288. http:// dx.doi.org/10.1046/j.1523-1739.1993.07020279.x.

MCDONNELL, M.J., 1986. Old field vegetation height and the dispersal pattern of bird-disseminated woody plants. Bulletin of the Torrey Botanical Club, vol. 113, no. 1, pp. 6-11. http://dx.doi. org/10.2307/2996227.

MCDONNELL, M.J. and STILES, E.W., 1983. The structural complexity of the old field vegetation and the recruitment of birddispersed plant species. Oecologia, vol. 56, no. 1, pp. 109-116. http://dx.doi.org/10.1007/BF00378225.

MCKEY, D., 1975. The ecology of coevolved seed dispersal systems. In: L.E. GILBERT and P.H. RAVEN, eds. Coevolution of animals and plants. Austin: University of Texas Press, pp. 159-191.

MELO, V.A., GRIFFITH, J.J., DE MARCO JÚNIOR, P., SILVA, E., SOUZA, A.L. de, GUEDES, M.C. and OZÓRIO, T.F., 2000. Efeito de poleiros artificiais na dispersão de sementes por aves. Revista Árvore, vol. 24, no. 3, pp. 235-240.

MOERMOND, T.C. and DENSLOW, J.S., 1985. Neotropical avian frugivores: patterns of behavior, morphology, and nutrition with consequences for fruit selection. Ornithological Monographs, vol. 36, no. 36, pp. 865-897. http://dx.doi.org/10.2307/40168322.

PAULA, A., SILVA, A.F., MARCO JÚNIOR, P., SANTOS, F.A.M. and SOUZA, A.L., 2004. Sucessão ecológica da vegetação arbórea em uma Floresta Estacional Semidecidual, Viçosa, MG, Brasil. Acta Botanica Brasílica, vol. 18, no. 3, pp. 407-423. http://dx.doi. org/10.1590/S0102-33062004000300002. 
PINHEIRO, M.H.O. and MONTEIRO, R., 2009. Análise estrutural e considerações sobre a dinâmica sucessional de dois fragmentos florestais semideciduais do Jardim Botânico Municipal de Bauru, SP, Brasil. Acta Botanica Brasílica, vol. 23, no. 4, pp. 968-975. http://dx.doi.org/10.1590/S0102-33062009000400007.

PIZO, M.A., 1997. Seed dispersal and predation in two populations of Cabralea canjerana (Meliaceae) in the Atlantic forest of southeastern Brazil. Journal of Tropical Ecology, vol. 13, no. 04, pp. 559-578. http://dx.doi.org/10.1017/S0266467400010713.

POTASCHEFF, C.M., LOMBARDI, J.A. and LORENZI, H., 2010. Angiospermas arbóreas do campus da Universidade Estadual Paulista Júlio de Mesquita, Rio Claro (SP). Bioikos, vol. 24, no. 1, pp. 21-30.

RELORA, 2014 [viewed 30 August 2013]. Species list of Brazil flora [online]. Rio de Janeiro: Botanic Garden of Rio de Janeiro. Available from: http://floradobrasil.jbrj.gov.br.

SHIELS, A.B. and WALKER, L.R., 2003. Bird perches increase forest seeds on Puerto Rico landslides. Restoration Ecology, vol. 11, no. 4, pp. 457-465. http://dx.doi.org/10.1046/j.1526100X.2003.rec0269.x.

SICK, H., 1997. Ornitologia brasileira. Rio de Janeiro: Nova Fronteira. $912 \mathrm{p}$.
SNOW, D.W., 1981. Tropical frugivorous birds and their food plants: a world survey. Biotropica, vol. 13, no. 1, pp. 1-14. http:// dx.doi.org/10.2307/2387865.

TABANEZ, M., ZANCHETA, D. and RAIMUNDO, S., 2003. Plano de manejo do Parque Estadual de Porto Ferreira. São Paulo: Instituto Florestal. $121 \mathrm{p}$.

TOMAZI, A.L., ZIMMERMANN, C.E. and LAPS, R.R., 2010. Poleiros artificiais como modelo de nucleação para restauração de ambientes ciliares: caracterização da chuva de sementes e regeneração natural. Biotemas, vol. 23, no. 3, pp. 125-135.

WUNDERLE JUNIOR, J.M., 1997. The role of animal seed dispersal in accelerating native forest regeneration on degraded tropical lands. Forest Ecology and Management, vol. 99, no. 1-2, pp. 223-235. http://dx.doi.org/10.1016/S0378-1127(97)00208-9.

ZAHAWI, R.A., HOLL, K.D., COLE, R.J. and REID, L., 2012. Testing applied nucleation as a strategy to facilitate tropical forest recovery. Journal of Applied Ecology, vol. 50, no. 1, pp. 88-96. http://dx.doi.org/10.1111/1365-2664.12014.

ZANINI, L. and GANADE, G., 2005. Restoration of Araucaria Forest: the role of perches, pioneer vegetation and soil fertility. Restoration Ecology, vol. 13, no. 3, pp. 507-514. http://dx.doi. org/10.1111/j.1526-100X.2005.00063.x. 